\title{
Variation in Clavicular Origin of Sternocleidomastoid Muscle
}

\author{
Variaciación en el Origen Clavicular del Músculo Esternocleidomastoideo \\ *Adelmar Afonso de Amorim Júnior; *Carla Cabral dos Santos Accioly Lins; \\ *Ana Paula dos Santos Cardoso \& **Caroline Guimarães Damascena
}

\begin{abstract}
AMORIM JR., A. A.; LINS, C. C. S. A.; CARDOSO, A. P. S. \& DAMASCENA, C. G. Variation in clavicular origin of sternocleidomastoid muscle. Int. J. Morphol., 28(1):97-98, 2010.

SUMMARY: The sternocleidomastoid is a muscle with a great extension that occupies the cervical region and is extended obliquely from the head to the trunk. Its morphology is not uniform, once its ends are wide and slim while its medial edge is thick and narrow. The aim of our work was to relate a case of variation in clavicular origin of this muscle that was extended beyond the half of clavicle laterally, in both sides of the neck.
\end{abstract}

KEY WORDS: Sternocleidomastoid muscle; Anatomical variation.

\section{INTRODUCTION}

The region of the neck is considered one of the more complex areas of human body, due to the fact of being related to some important structures. This way the professional must have an enhanced knowledge about these structures. In order to perform an approach the sternocleidomastoid muscle is an anatomic referential, because it divides the neck in trigones, facilitating the clinical and surgical procedures.

It is located in the anterolateral region of the neck, under the skin. It has two heads: one fixed in the esternal manubrium and the clavicular portion in the superior face of medial third of clavicle, and its insertion is in temporal mastoid process extended up to the superior nuchal line of occipital bone. Thus it is an important muscular point of reference (Moore \& Dalley, 2007).

Due to its obliquity, the sternocleidomastoid muscle realizes the movements of flexion, rotation and inclination of the head, and it is considered an important accessory muscle of inspiration (Kendall, 1995).

Its nervous supply is attributed to the cranial accessory nerve (XI), which in general passes through the muscle; as well as by ventral branches of the second, the third and sometimes the fourth spinal nerves (Machado, 1992). Its blood supply comes from the arteries: superior thyroid, occipital artery and posterior auricular artery which are branches of external carotid artery; and is also irrigated by the suprascapular artery, a branch of subclavian artery (Gray, 1977).

\section{RELATE OF A CASE}

During the routine dissecations of the graduation course of medicine of the Federal University of Pernambuco, Recife-PE, Brazil; in the region of the neck of a male adult corpse, we found a rare case of variation of sternocleidomastoid muscle. This variation was characterized in the clavicular origin by an aditional portion which was laterally expanded (Fig. 1).

\section{DISCUSSION}

The knowledge of anatomical variations is very important for the professionals of medical area because when these workers face rare clinical cases the diagnosis and treatment become more difficult, demanding a large clinical experience of these professionals to deal with these situations.

* Departamento de Anatomia de la Universidade Federal de Pernambuco, Recife-PE, Brazil.

**A Alumnas del Curso de Fisioterapia de la Universidad Federal de Pernambuco, Recife-PE, Brazil. 


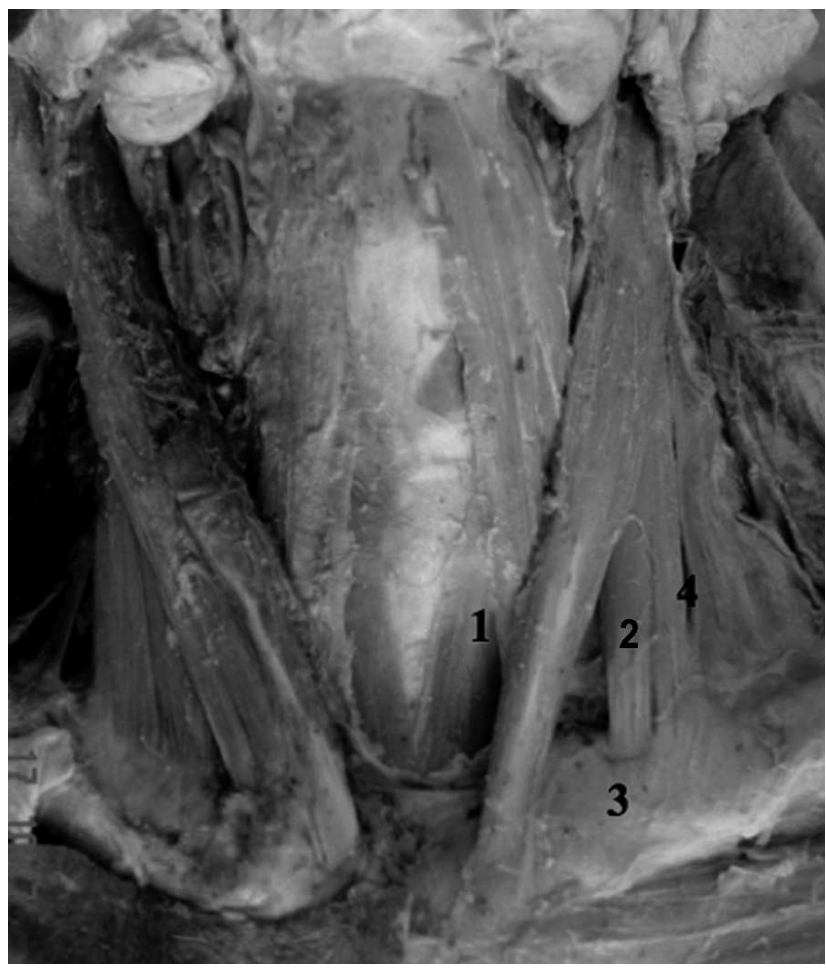

The sternocleidomastoid muscle shows a great variation in the extension of the origin of clavicle: in some cases the clavicular head can be as narrow as the esternal; in other cases it can have about $7.5 \mathrm{~cm}$ of width. When the clavicular origin is wide, it is occasionally subdivided in various issues; separated by narrow intervals. The adjacent edges of sternocleidomastoid and trapezius muscles are rarely found in contact (Gray).

According to Testut \& Latarjet (1975) this muscle can show an inferior aponeurotic insertion, it can also, by its posterior edge, join the trapezius muscle, as well as be divided in issues: sternomastoid, sternooccipital, cleidomastoid and cleidooccipital. According to Ramesh et al. (2007) the aditional clavicular heads are narrow and separated by a wide triangular interval, which corresponds to a surface depression, the lesser supraclavicular fossa. In accordance with them, Dufour (2004) affirmed that these four heads can be distributed in two plans: one superficial and another deep. Our data are different from the ones found in the literature, once the aditional portion found is widely extended laterally without divisions.

Fig. 1. Variation of the sternocleidomastoid muscle. 1. Sternal origin; 2. Clavicular origin; 3. Claviccle; 4. Anatomical variation.

AMORIM JR., A. A.; LINS, C. C. S. A.; CARDOSO, A. P. S. \& DAMASCENA, C. G. Variaciación en el origen clavicular del músculo esternocleidomastoideo. Int. J. Morphol., 28(1):97-98, 2010.

RESUMEN: El esternocleidomastóideo es un músculo de gran extensión en la región cervical con trayecto oblicuo desde la cabeza hasta el tronco. Su morfología no es uniforme, debido a que sus extremos son anchos y finos, mientras que él es grueso y estrecho en su borde medial. El objetivo de este trabajo fue relatar un caso de la variación en el origen clavicular de este músculo que se extendí mas allá de la mitad de la clavícula en dirección lateral, en ambos lados del cuello.

PALABRAS CLAVE: Músculo esternocleidomastoideo; Variación anatómica.

\section{REFERENCES}

Dufour, M. Anatomia do Aparelho Locomotor: Cabeça e tronco. Rio de Janeiro, Guanabara Koogan, 2004. p.358.

Gray, H. F. R. S. Anatomia. 29a Ed. Rio de Janeiro, Guanabara Koogan, 1977. p.1147.

Kendall, P. Músculos, provas e funções. $4^{\mathrm{a}}$ Ed. São Paulo, Manole, 1995. p.329.

Machado, A. B. M. Neuroanatomia funcional. Rio de Janeiro, Atheneu, 1992.

Moore, K. L. \& Dalley, A. F. Anatomia Orientada para a Clínica. $5^{\text {a }}$ Ed. Rio de Janeiro, Guanabara Koogan, 2007.
Ramesh, R. T.; Vishnumaya, G.; Prakashandra, S. K. \& Suresh, R. Variation in the origin of sternocleidomastoid muscle. A case report. Int. J. Morphol., 25(3):621-3, 2007.

Testut, L. \& Latarjet, A . Tratado de Anatomía Humana. Barcelona, Salvat, 1975. p.1237.

Correpondence to:

Prof. Carla Cabral dos Santos Accioly Lins

Department of Anatomy

Universidade Federal de Pernambuco

Rua manuel de carvalho, $n^{\circ} 310$, apt 303 , aflitos

CEP 52050-370, Recife- PE

BRAZIL

Email: cabralcarla1@hotmail.com

Received: 02-06-2009

Accepted: 09-01-2010 